Environment Conservation Journal 14(1\&2) 9-20, 2013

ISSN 0972-3099 (Print) 2278-5124 (Online)

Abstracted and Indexed

\title{
Quality characteristics of effluent receiving waters of Benin River adjacent to a lubricating oil producing factory, Nigeria
}

\author{
Samuel Omorovie Akporido
}

Received: 21.12.2012

Accepted: 11.03.2013

\begin{abstract}
Untreated (or partially treated) effluents are capable of polluting a receiving water body. An environmental audit of the Benin river adjacent to a lubricating oil producing factory was carried out. Dry and rainy seasons effluent and water samples were collected for two years (water samples from seven sampling stations i.e. two upstream and five downstream). Physicochemical variables (including oil variables) were analyzed by standard methods and toxic metals by flame atomic absorption spectrometry. Important results include Oil and Grease $\left(2270 \pm 480 \mu \mathrm{gl}^{-1}\right)$, total petroleum hydrocarbon $\left(2010 \pm 340 \mathrm{\mu gl}^{-1}\right), \mathrm{Pb}\left(146 \pm 55 \mathrm{gl}^{-1}\right), \mathrm{Ni}\left(1880 \pm 630 \mathrm{\mu gl}^{-1}\right)$ and $\mathrm{pH}(6.02 \pm 0.09)$. Some of these variables and metals exceeded guidelines values for drinking water quality. Water is polluted and needs to be rigorously treated before use for drinking purpose.
\end{abstract}

Keywords:Benin river, lubricating oil producing factory, physico chemical variables, toxic metals, oil and grease, total petroleum hydrocarbon, drinking water quality, flame atomic absorption spectrometry

\section{Introduction}

Important sources of petroleum hydrocarbons and heavy metals in the environment include petroleum prospecting and processing industry, petroleum refining and petrochemical industries, and wastes from auto- mobile mechanic workshops (waste containing used and unused lubricating oils) (Forstner and Whittman, 1983; GESAMP, 1993). The Niger Delta environment is known to have received high concentrations of petroleum hydrocarbons from the upstream sector of the petroleum industry through the instrumentation of oil spillages (Horsefall and Spiff, 2002; UNDP, 2006). It has been estimated that three million barrels of crude oil have been spilled into the Niger delta environment in 6817 separate spills between 1976 and 2001 (UNDP, 2006). The effect of the presence of high concentrations of petroleum hydrocarbons can be severe; they include damage to and loss of biodiversity, depletion of arable land, depletion of available potable water and blockage of water ways (Nwilo and Badejo, 2007; NRC, 2003; Luiselli et al., 2004; Luiselli et al., 2006;

\section{Author's Address}

Department of Chemistry, Delta State University, P.M. B. 1 Abraka, Delta State, Nigeria.

Email: samaccess2006@yahoo.com
Odokuma and Okpokwasili, 2004; Omo-Irabor et al., 2011). Reported studies of effects of the petroleum industry (both upstream and downstream sectors) on the environment of the Niger Delta have revealed that high concentrations of total petroleum hydrocarbon (TPH), polynuclear aromatic hydrocarbons and trace heavy metals are present in waters, sediments and soils of the Niger Delta (Ekpo et al., 2012; Onianwa et al.,2001; Iwegbue et al., 2008; Nduka and Orisakwe, 2011; Davies and Abowei, 2009; Akporido and Imah, 2009; Otukunefor and Obiekwu, 2005; UNEP, 2011).The physicochemical characteristics of a refinery effluent and the physicochemical characteristic of water and sediment of an effluent receiving water body was investigated (Otukunefor and Obiekwu, 2005). They observed that treated refinery effluent contained very high concentrations of phenol (11.06 mg/L), oil and grease (7.52 mg/L), ammonia (8.52 mg/L), COD (91.76 mg/L), TDS (390.6 $\mathrm{mg} / \mathrm{L})$ and phosphate (6.2 $\mathrm{mg} / \mathrm{L})$, but low concentrations of sulphide, nickel, lead, copper and chromium which were undetected. They also observed high concentrations of phenol (5.13 $16.38 \mathrm{mg} / \mathrm{L})$, oil and grease $(10.56-15.23 \mathrm{mg} / \mathrm{L})$ and ammonia (4.31 - $13.17 \mathrm{mg} / \mathrm{l})$ in the receiving water. The Benin river takes it source from an area 
about $150 \mathrm{~km}$ northeast of Koko town and flows through Koko ton and its adjoining area into the Bight of Benin. The river serves the people of the area for dinking purpose, for fishing and for transport. The adjoining land is used for farming. Farm products obtained from the area include: vegetables, palm oil, cassava and yam. There has not been any reported incident of crude oil spillage in the vicinity of Koko town. There has however been the incident of the deposition of hazardous waste originating from Italy in a part of Koko town which attracted the attention of the Federal Government of Nigeria and the international community (Kocasoy, 2003). A large proportion of the waste was finally evacuated and re-exported to Italy (Kocasoy, 2003). Most the reported works on the Niger delta environment have so far been focused on the effect of petroleum prospecting and processing industry as already indicated. Some work has also been carried out on the effect of effluents from refineries and petroleum product depots (UNEP, 2011; Otukunefor and Obiekwu, 2005) and on auto-mobile mechanic waste dumps (Iwegbue et al., 2008; Akporido and Imah, 2009). In one of these studies elevated concentrations of TPH was observed in which the source was inferred to be from the deliberate or in deliberate spilling of used and unused lubricating oil on the soil (Iwegbue et al. 2008). No work has however been reported on the effect of effluents from a lubricating oil producing factory on the water, sediment and soil of an area close to such a factory. The hypothesis of this study is to assess the effect of effluents from a lubricating oil producing factory on the physicochemical parameters, the toxic metal contents and the oil contents (total organic extracts and total petroleum hydrocarbons) in waters of Benin River adjacent to the factory it is expected that, effluents from such a factory should affect these parameters in water of such an environment. There is also a dearth of information on the effect of effluents from lubricating oil producing factories in the Niger Delta region. The present study examined the effect of effluents from a lubricating oil producing factory on the waters of a river which receives such effluents by determining some physicochemical variables, total petroleum hydrocarbons (TPH) total organic extracts (TOE), and selected toxic metals of both the effluents and waters of the receiving river.

\section{Material and methods}

The study area is shown in Figure 1 (Map of study area showing a section of Benin River and the location of the lubricating oil factory) Water samples were collected from seven sampling stations. Two of the sampling stations are located upstream from the point of entry of effluents into the river. One sampling station is at the point of entry of effluents into the river and four others sampling stations are located downstream from this point successively. The two upstream stations are at Ubakporo (UBAK) and at Arunologbo (ARUN). The sampling station at the point of entry of effluent is designated as Point of Entry of effluents (PEE). The other four sampling stations are at Ajalugbeti (AJA), this is followed by Uba-Iro (UBA), Uba-Tailor (UB-TA) and at Ilogun (ILOG). The Benin River flows from Ethiope West Local Government of delta State in the direction southwest into the Bight of Benin in the Atlantic Ocean. It flows past Koko town in which is situated the lubricating oil producing factory. Fig. 1 is map of study area showing a section of Benin River and location of Lubricating oil producing factory in Koko town. Water samples were collected twice every season (i.e. once in each quarter of the year). Samples were collected in dry and rainy seasons for two years. Effluent samples were also collected each time water samples were collected from the river. Effluent samples were collected from the conduit pipe where it discharges effluents into the river.

Samples were taken for the following parameters: $\mathrm{pH}$, temperature, total suspended solids (TSS), total dissolved solid (TDS), dissolved oxygen (DO) biochemical oxygen demand $\left(\mathrm{BOD}_{5}\right)$, chemical oxygen demand (COD), oil and grease (O\&G), and total petroleum hydrocarbon (TPH) and the heavy metals ( $\mathrm{Ni}, \mathrm{Cd}, \mathrm{Pb}, \mathrm{Cr}$, and $\mathrm{Zn}$ ).

The period of sampling was from June 2007 to March 2009. Grab samples of water were collected manually from near the middle axis of the river at the surface (1 $\mathrm{m}$ to the surface) and at mid-depth by covering the mouth of the sample bottle and opening it at the desired depth to collect the water samples.

The bottle lid is now replaced before withdrawing the sampling bottle from the water. The effluent samples were collected by compositing grab 




Figure 1: Map of study area showing a section of Benin River and the location of the lubricating oil factory Source: Directorate of Land and Survey Governor's Office, Asaba, Delta State, Nigeria

samples collected every 20 mins for 2 hrs. Water and effluent samples were preserved for each parameter as described in standard methods (APHA-AWWA-WEF, 1995). The temperature of samples was determined at the site with mercury bulb thermometers. The $\mathrm{pH}$ of water samples was determined by a portable $\mathrm{pH}$ - meter ( $\mathrm{pH}$-meter model test WP) at the site. The determination of TSS was carried out by filtering water sample using gooch crucible -suction pump system and drying the filtered solid in an oven at $103^{\circ} \mathrm{C}$ to constant weight (APHA-AWWA-WEF, 1995). The TDS was determined by evaporating the filtrate (in the TSS determination) in an evaporating dish in a steam bath and drying the residue in an evaporating dish in an oven at $180{ }^{\circ} \mathrm{C}$ to constant weight
(APHA-AWWA-WEF, 1995). DO was determined by the iodometric method (azide modification) as described in standard method (APHA-AWWAWEF, 1995). The 5-days BOD test was employed in the determination of $\mathrm{BOD}_{5}$ of water samples (APHA-AWWA-WEF, 1995). The open reflux method was used in the determination of COD of samples (APHA-AWWA-WEF, 1995). The O\&G of samples was determined by partition-infrared method with oil obtained from the lubricating oil factory acting as reference oil and as in standard method (5520C) (APHA-AWWA-WEF, 1995). The TPH of water samples was determined from the hexane extract used for the oil and grease measurement by first carrying out a clean up procedure on the extract by the addition of $4 \mathrm{~g}$. of 
activated silica gel with stirring using a magnetic stirrer for $5 \mathrm{~min}$. and measuring TPH by partitioninfrared (method 5520F) (APHA-AWWA-WEF, 1995).Water samples were pre-concentrated by evaporation simultaneously with digestion by addition of $5 \mathrm{ml}$ Concentrated. $\mathrm{HNO}_{3}$. Toxic metals ( $\mathrm{Ni}, \mathrm{Cd}, \mathrm{Pb}, \mathrm{Cu}$ and $\mathrm{Zn}$ ) were determined from the digest solution by flame AAS. Details of experimentation are as stated in standard methods (APHA-AWWA-WEF, 1995). A quality assurance programme was put in place in the study and it involved determination of blanks and duplicates, determination of glucose-glutamic acid check for $\mathrm{BOD}_{5}$ determinations, determination of \% recovery for COD by determining COD on standard solutions of potassium hydrogen phthalate (KHP) (i.e. solution which contains $425 \mathrm{mg} / \mathrm{L}$ of KHP) and comparing the mean of five determinations to the theoretical value of $500 \mathrm{mgl}^{-1}$ (APHA-AWWAWEF, 1995). The percentage recoveries of O\&G, $\mathrm{TPH}$ and the five toxic metals were also determined. The following average percentage recoveries were obtained for five determination of each parameter: COD (93.2 \pm 4.7\%), O\&G (93.6 $\pm 8.4)$, ТPH (95.2 $\pm 7.7 \%)$, Ni (91.4 $\pm 6.3 \%)$, Cd (92.7 $\pm 9.1 \%), \mathrm{Pb}(99 \pm 5.8 \%), \mathrm{Cr}(98.3 \pm 7.5 \%)$ and Zn (101 \pm 8.7\%). These percentage recoveries all falls within the range $90-110$ which means good percentage recoveries were obtained for all the parameters. Using Microsoft Excel (Microsoft Corporation LTD), ANOVA-single factor analysis was used for the comparison of means of each of the variables in the four seasons studied (two dry and two rainy seasons) and the mean of each variable in five sampling stations in the study area, and the t-test (two sample, assuming equal variance) was used to compare the means of some of the variables of the study area with those of the control area. The Pearson 2-tailed test was used for the correlation of the values of all variables (with the exception of the $\mathrm{pH}$ values) within the Statistic Package for the Social Sciences (SPSS) (version 17) (SPSS, Chicago).

\section{Results and Discussion}

The results obtained shows that the average concentrations of the two oil parameters in the study area i.e. O \& G $(2270 \pm 480 \mu \mathrm{g} / \mathrm{L}$ and TPH $(2010 \pm 340 \mu \mathrm{g} / \mathrm{L})$ are high as expected. Other results which also indicated that the quality of water in the study area is low are the average values of Ni $(1880 \pm 630 \mu \mathrm{g} / \mathrm{L}), \mathrm{Pb}(146 \pm 55 \mu \mathrm{g} / \mathrm{L})$, Zn $(62 \pm 42 \mu \mathrm{g} / \mathrm{L}), \mathrm{Cd}(3.0 \pm 5.3 \mu \mathrm{g} / \mathrm{L})$, COD $(80 \pm 38$ $\mu \mathrm{g} / \mathrm{L})$ and DO $(2.96 \pm 0.90 \mu \mathrm{g} / \mathrm{L})$. A definite pattern in the variation of the values of measured parameters with distance from point of discharge of effluents to downstream to the furthest sampling station ( i.e. ILOGUN) was not observed (Table 2). The differences in the values of the measured parameters with sampling stations were only statistically significant for COD and Cd using ANOVA- single factor analysis.. Also none of the values of measured parameters are highest at point of discharge of effluent as might be expected. The values of most parameters were higher in the study area (downstream) sampling stations than in the control area sampling stations (Tables $1 \& 3$ ).

Cd was not detected in any of the control sampling stations but significant amount was observed in each of the study area sampling stations. Also a comparison of the values of some of the measured variables within the study area with those within the control area using t-test (two sample, assuming equal variance) shows that the differences were statistically significant for COD, O \& G, TPH, Ni, $\mathrm{Pb}$, and $\mathrm{Zn}$. The differences in the concentrations of $O$ \& G and TPH between the study area and the control area indicates that a significant amount of oil related substances entered the river at the point of discharge of effluents into the river (PEE). A comparison of the values of the physicochemical characteristics in the different seasons shows that there are no statistically significant changes in the physicochemical characteristics of study area water with seasons (ANOVA-Single factor) (Table 2). The concentrations of $\mathrm{Ni}\left(1970 \pm 670 \mathrm{\mu gl}^{-1}\right), \mathrm{O} \& \mathrm{G}$ $\left(2340 \pm 480 \mathrm{\mu gl}^{-1}\right)$ and TPH $\left(2040 \pm 350 \mu^{-1}{ }^{-1}\right)$ were however much higher in the second dry season. The

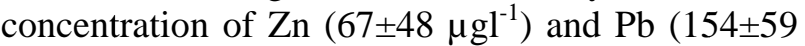
$\mu \mathrm{gl}^{-1}$ ) were higher in the second rainy seasons than the concentrations for the two parameters in the other three seasons.Also, a comparison of concentrations of heavy metals in effluents with two national effluent limitation guidelines (Nigeria) i.e. effluent limitation guidelines of the Federal environmental protection agency (FEPA) (now Federal ministry of environment (FMEnv)) (FEPA, 1991) and that of the Department of Petroleum Resources (DPR) (DPR, 2002) shows the 
Quality characteristics of effluent receiving waters

Table 1: Average values of Physico chemical characteristics of each Sampling Station

\begin{tabular}{lccccccc}
\hline \multirow{2}{*}{ Parameters } & \multicolumn{2}{c}{$\begin{array}{l}\text { Upstream(control) } \\
\text { sampling Stations }\end{array}$} & \multicolumn{5}{c}{ Downstream (Study area) Sampling Stations } \\
\cline { 2 - 7 } & UBAK & ARUN & PEE & AJA & UBA & UB-TA & ILOG \\
\hline Temp. ${ }^{0} \mathrm{C}$ & $32.1 \pm 1.0$ & $32.4 \pm 0.9$ & $30.9 \pm 0.6$ & $30.5 \pm 0.8$ & $30.4 \pm 1.1$ & $30.8 \pm 1.3$ & $31.8 \pm 0.7$ \\
$\mathrm{pH}$ at $25^{0} \mathrm{C}$ & $6.08 \pm 0.04$ & $6.05 \pm 0.06$ & $6.0 \pm 0.04$ & $5.96 \pm 0.11$ & $6.02 \pm 0.09$ & $6.07 \pm 0.04$ & $6.06 \pm 0.10$ \\
$\mathrm{TSS}\left(\mathrm{mgl}^{-1}\right)$ & $6.1 \pm 1.1$ & $7.6 \pm 1.5$ & $67 \pm 1.6$ & $6.2 \pm 1.1$ & $6.1 \pm 1.4$ & $6.5 \pm 1.4$ & $7.5 \pm 2.7$ \\
$\mathrm{TDS}\left(\mathrm{mgl}^{-1}\right)$ & $19.8 \pm 1.6$ & $22.1 \pm 1.7$ & $18.6 \pm 4.4$ & $21.1 \pm 6.3$ & $24.0 \pm 6.1$ & $19.8 \pm 2.8$ & $28.5 \pm 3.9$ \\
$\mathrm{DO}\left(\mathrm{mgl}^{-1}\right)$ & $4.36 \pm 0.68$ & $4.24 \pm 0.32$ & $3.7 \pm 1.3$ & $2.56 \pm 0.51$ & $3.25 \pm 0.56$ & $2.12 \pm 0.19$ & $3.18 \pm 0.59$ \\
$\mathrm{BOD}{ }_{5}\left(\mathrm{mgl}^{-1}\right)$ & $7.48 \pm 0.91$ & $5.20 \pm 0.96$ & $7.7 \pm 2.3$ & $5.3 \pm 2.0$ & $6.1 \pm 2.6$ & $4.6 \pm 2.4$ & $8.34 \pm 0.64$ \\
$\mathrm{COD}\left(\mathrm{mgl}^{-1}\right)$ & $65 \pm 12$ & $13.4 \pm 4.9$ & $114 \pm 11$ & $120 \pm 5.8$ & $78 \pm 19$ & $68 \pm 13$ & $21.7 \pm 5.3$ \\
$\left.\mathrm{O} \&{\mathrm{G}\left(\mu \mathrm{gl}^{-1}\right)}^{1}\right)$ & $1810 \pm 300$ & $2060 \pm 250$ & $1960 \pm 230$ & $2380 \pm 330$ & $2300 \pm 640$ & $2260 \pm 460$ & $2470 \pm 590$ \\
$\mathrm{TPH}\left(\mu \mathrm{gl}^{-1}\right)$ & $1540 \pm 80$ & $2000 \pm 250$ & $1740 \pm 140$ & $2170 \pm 250$ & $2010 \pm 520$ & $2160 \pm 310$ & $1980 \pm 240$ \\
$\mathrm{Ni}\left(\mu \mathrm{gl}^{-1}\right)$ & $940 \pm 580$ & $1390 \pm 1100$ & $1730 \pm 690$ & $1660 \pm 250$ & $1630 \pm 240$ & $1630 \pm 570$ & $2740 \pm 500$ \\
$\mathrm{Cd}\left(\mu \mathrm{gl}^{-1}\right)$ & $\mathrm{ND}$ & $\mathrm{ND}$ & $2.4 \pm 1.8$ & $9.6 \pm 9.1$ & $1.5 \pm 3.5$ & $2.4 \pm 1.4$ & $0.38 \pm 0.52$ \\
$\mathrm{~Pb}\left(\mu \mathrm{gl}^{-1}\right)$ & $107 \pm 110$ & $63 \pm 64$ & $154 \pm 36$ & $134 \pm 94$ & $134 \pm 54$ & $147 \pm 49$ & $163 \pm 20$ \\
$\mathrm{Cr}\left(\mu \mathrm{gl}^{-1}\right)$ & $0.38 \pm 0.52$ & $1.00 \pm 0.93$ & $0.50 \pm 0.53$ & $0.50 \pm 0.76$ & $0.25 \pm 0.46$ & $0.50 \pm 0.76$ & $0.25 \pm 0.46$ \\
$\mathrm{Zn}\left(\mu \mathrm{gl}^{-1}\right)$ & $22.8 \pm 3.1$ & $20.6 \pm 3.9$ & $58 \pm 15$ & $61.4 \pm 9.9$ & $56 \pm 50$ & $32 \pm 19$ & $103 \pm 61$ \\
\hline
\end{tabular}

Table 2: Average Values of Physicochemical Parameter in each Season

\begin{tabular}{lcccc}
\hline Parameters & First Dry Season & $\begin{array}{c}\text { First Rainy } \\
\text { Season }\end{array}$ & $\begin{array}{c}\text { Second Dry } \\
\text { Season }\end{array}$ & $\begin{array}{c}\text { Second Rainy } \\
\text { Season }\end{array}$ \\
\hline Temperature ${ }^{0} \mathrm{C}$ & $30.6 \pm 0.8$ & $30.9 \pm 0.7$ & $31.3 \pm 1.3$ & $30.7 \pm 1.1$ \\
$\mathrm{pH}$ & $6.04 \pm 0.03$ & $6.01 \pm 0.10$ & $6.04 \pm 0.05$ & $6.01 \pm 0.15$ \\
$\mathrm{TSS}\left(\mathrm{mgl}^{-1}\right)$ & $5.6 \pm 1.2$ & $6.8 \pm 1.5$ & $6.7 \pm 2.1$ & $7.3 \pm 1.8$ \\
$\mathrm{TDS}\left(\mathrm{mgl}^{-1}\right)$ & $23.0 \pm 5.8$ & $22.0 \pm 5.5$ & $22.0 \pm 6.2$ & $22.7 \pm 6.7$ \\
$\mathrm{DO}\left(\mathrm{mgl}^{-1}\right)$ & $2.58 \pm 0.74$ & $3.10 \pm 0.82$ & $3.0 \pm 1.1$ & $3.21 \pm 0.88$ \\
$\mathrm{BOD}{ }_{5}\left(\mathrm{mgl}^{-1}\right)$ & $5.6 \pm 2.5$ & $6.3 \pm 2.7$ & $7.0 \pm 2.0$ & $6.7 \pm 2.7$ \\
$\mathrm{COD}\left(\mathrm{mgl}^{-1}\right)$ & $79 \pm 41$ & $82 \pm 40$ & $79 \pm 37$ & $81 \pm 39$ \\
$\mathrm{O} \&{\mathrm{G}\left(\mu l^{-1}\right)}_{\mathrm{TPH}\left(\mu \mathrm{gl}^{-1}\right)}^{2260 \pm 440}$ & $2260 \pm 500$ & $2340 \pm 480$ & $2230 \pm 580$ \\
$\mathrm{Ni}\left(\mu \mathrm{gl}^{-1}\right)$ & $1990 \pm 270$ & $2000 \pm 350$ & $2040 \pm 350$ & $2030 \pm 430$ \\
$\mathrm{Cd}\left(\mu \mathrm{gl}^{-1}\right)$ & $1880 \pm 630$ & $1820 \pm 680$ & $1970 \pm 670$ & $1830 \pm 640$ \\
$\mathrm{~Pb}\left(\mu \mathrm{gl}^{-1}\right)$ & $2.6 \pm 6.9$ & $3.4 \pm 4.1$ & $3.0 \pm 4.4$ & $3.0 \pm 6.1$ \\
$\mathrm{Cr}\left(\mu \mathrm{gl}^{-1}\right)$ & $142 \pm 53$ & $148 \pm 57$ & $141 \pm 58$ & $154 \pm 59$ \\
$\mathrm{Zn}\left(\mu \mathrm{gl}^{-1}\right)$ & 0.00 & $0.60 \pm 0.70$ & $0.50 \pm 0.71$ & $0.50 \pm 0.53$ \\
\hline
\end{tabular}

following: the average concentration of $\mathrm{Zn}$ in DPR effluent guideline Value $\left(30.0 \mu \mathrm{g} / \mathrm{l}^{-1}\right)$. These effluent $\left(5140 \pm 710 \mathrm{\mu gl}^{-1}\right)$ exceeded both the FEPA results indicate that the effluents from the guideline $\left(5000 \mathrm{ugl}^{-1}\right)$ and the DPR guideline value lubricating oil producing factory are polluted and ( $1500 \mathrm{\mu gl}^{-1}$ ), The average concentration of $\mathrm{Pb}$ in have capability to pollute a receiving water body. A effluent $\left(2380 \pm 210 \mathrm{\mu gl}^{-1}\right)$ exceeded both the FEPA very important observation however is that the $\left(50.0 \mathrm{\mu gl}^{-1}\right)$ and the DPR $\left(50.0 \mathrm{\mu gl}^{-1}\right)$ effluent average concentration of $\mathrm{Ni}$ in effluent $(10.2 \pm 5.2$ guideline values, while the average concentration of $\mathrm{\mu gl}^{-1}$ ) exceeded the guideline value for FEPA (10.0 $\mathrm{Cr}$ in effluent $\left(35.0 \pm 5.5 \mathrm{\mu gl}^{-1}\right.$ ) exceeded only the $\mathrm{\mu gl}^{-1}$ ) slightly (DPR have no value for $\mathrm{Ni}$ ) and is 
Table 3: Average values of Physico chemical characteristics and heavy metals in study and control areas

\begin{tabular}{|c|c|c|}
\hline Parameters & Study Area & Control Area \\
\hline Temperature ${ }^{0} \mathrm{C}$ & $30.9 \pm 1.0$ & $32.0 \pm 0.9$ \\
\hline $\mathrm{pH}$ at $25^{\circ} \mathrm{C}$ & $6.02 \pm 0.09$ & $6.06 \pm 0.05$ \\
\hline TSS $\left(\mathrm{mgl}^{-1}\right)$ & $6.6 \pm 1.7$ & $6.9 \pm 1.5$ \\
\hline $\mathrm{TDS}\left(\mathrm{mgl}^{-1}\right)$ & $22.4 \pm 5.8$ & $21.0 \pm 2.0$ \\
\hline DO $\left(\mathrm{mgl}^{-1}\right)$ & $2.96 \pm 0.90$ & $4.30 \pm 0.51$ \\
\hline $\mathrm{BOD}_{5}\left(\mathrm{mgl}^{-1}\right)$ & $6.4 \pm 2.5$ & $6.3 \pm 1.5$ \\
\hline $\operatorname{COD}\left(\mathrm{mgl}^{-1}\right)$ & $80 \pm 38$ & $39 \pm 28$ \\
\hline$O \& G\left(\mu \mathrm{gl}^{-1}\right)$ & $2270 \pm 480$ & $1930 \pm 300$ \\
\hline ТРН $\left(\mu \mathrm{gl}^{-1}\right)$ & $2010 \pm 340$ & $1770 \pm 300$ \\
\hline $\mathrm{Ni}\left(\mu \mathrm{gl}^{-1}\right)$ & $1880 \pm 630$ & $1170 \pm 890$ \\
\hline $\mathrm{Cd}\left(\mu \mathrm{gl}^{-1}\right)$ & $3.0 \pm 5.3$ & 0.00 \\
\hline $\mathrm{Pb}\left(\mu \mathrm{gl}^{-1}\right)$ & $146 \pm 55$ & $85 \pm 89$ \\
\hline $\operatorname{Cr}\left(\mu \mathrm{gl}^{-1}\right)$ & $0.40 \pm 0.59$ & $0.69 \pm 0.79$ \\
\hline $\mathrm{Zn}\left(\mu \mathrm{gl}^{-1}\right)$ & $62 \pm 42$ & $21.7 \pm 3.6$ \\
\hline
\end{tabular}

also much less than the average concentration obtained in the river water $\left(1880 \pm 630 \mathrm{\mu gl}^{-1}\right)$. This invariably means that the high average concentration of $\mathrm{Ni}$ in the river water does not come from the effluent of the factory. It is suspected that nickel containing materials must have entered the river some where upstream. High concentration of $\mathrm{Ni}$ was also observed in the waters of the two upstream sampling stations. A comparison of values of physico chemical characteristics and toxic metals obtained in this study with several guideline values (Table 3 ) gives the following: The average $\mathrm{pH}$ value $(6.02 \pm 0.09)$ falls below the range for maximum acceptable levels of the Canadian Drinking Water Standards (6.5 - 8.5) maximum admissible concentration (MAC) of EEC Drinking Water Standards (6.5 8.5) (Sayre, 1988), Permissible Limit (PL) of FEPA (6.5 - 8.5), Nigeria Water Quality: Drinking water standards (FEPA,1991) and the secondary maximum contaminant level (SMCL) of U.S.A. Secondary Drinking water Standards (This is nonenforceable) (USEPA, 2004). All these indicate that the water is slightly too acidic to serve as drinking water. The $\mathrm{O} \& \mathrm{G}$ value $(2270 \pm 480 \mu \mathrm{gl}$ $\left.{ }^{1}\right)$ and TPH value $\left(2010 \pm 340{\left.\mu \mathrm{gl}^{-1}\right)}^{-1}\right.$ exceeds the permissible limit of FEPA, Nigeria water quality: drinking water Standards $(50.0 \mu \mathrm{g} / \mathrm{L})$ (FEPA, 1991) which shows there is too much oil related substance in the water of the study area. The average concentration of $\mathrm{Ni}$ of the study area $(1880 \pm 630$ $\mu \mathrm{gl}^{-1}$ ) by far exceed the WHO's 2006 drinking water standards $\left(70.0 \mathrm{\mu gl}^{-1}\right)$ and the permissible limit of FEPA Drinking water standards $\left(50.0 \mathrm{\mu gl}^{-}\right.$ ${ }^{1}$ ). The average value of $\mathrm{Pb}$ in the study area (146 $\pm 55 \mathrm{\mu gl}^{-1}$ ) far exceeds all the guideline values (Table 3), these shows that water of the area is polluted for purpose of drinking and not fit to serve as drinking water. A comparison of the average values of the physicochemical variables and toxic metals of the water of the study area with some guidelines for non-drinking uses of water (Table 6) shows that: the average $\mathrm{pH}$ of water $(6.02 \pm 0.09)$ falls below the $\mathrm{pH}$ range for the following guidelines values: fine paper production of the pulp and paper industry $(6.8-7.0)$ of the Canadian water quality guideline (WQGs) (Canadian council of Resource and Environment Ministers (CCREM), 1987), Boiler feed water of power generating industry $(8.8$ - 9.4) of the Canadian WQGs (CCREM, 1987), food canning and freezing dried processes of the Beverage industry $(6.5-8.5)$ of the Canadian WQGs (CCREM,1987), limiting concentration of irrigation water $(7.0-8.5)$ of the Food and Agricultural Organization (FAO) Aquatic life protection water (freshwater) of the California State Water Quality Control Board (CSWQCB) (6.58.5) and dyeing process of the Textile industry (7.510.0) of the Federal Environmental Protection Agency (now Federal Ministry of environment). 
Quality characteristics of effluent receiving waters

Table 4: Comparison of average concentration of heavy metals in effluent with FEPA and DPR effluent limitation guideline values

\begin{tabular}{lcccl}
\hline $\begin{array}{l}\text { Heavy } \\
\text { metals }\end{array}$ & $\begin{array}{c}\text { Concentrations } \\
\text { of Heavy metals }\end{array}$ & $\begin{array}{c}\text { FEPA Interim } \\
\text { Effluent Limitation } \\
\text { Guidelines (FEPA, } \\
\text { 1991). }\end{array}$ & $\begin{array}{c}\text { DPR Effluents } \\
\text { Limitation } \\
\text { Guidelines (DPR, } \\
\text { 2000) }\end{array}$ & Inferences \\
\hline $\mathrm{Ni}\left(\mu \mathrm{gl}^{-1}\right)$ & 10.00 & $\begin{array}{c}\text { No guidelines } \\
\text { No guidelines }\end{array}$ & $\begin{array}{l}\text { Did not exceed any } \\
\text { of the guidelines } \\
\text { Did not exceed any } \\
\text { of the guidelines } \\
\text { Exceeded both } \\
\text { guidelines }\end{array}$ \\
$\mathrm{Zn}\left(\mu \mathrm{ggl}^{-1}\right)$ & $<5.00$ & 10.00 & 1,500 & $\begin{array}{l}\text { guideced both } \\
\text { Exceeded } \\
\text { guidelines }\end{array}$ \\
$\mathrm{Cr}\left(\mu \mathrm{gl}^{-1}\right)$ & $5140 \pm 720$ & 5000 & 50.0 & $\begin{array}{l}\text { Exceeded DPR } \\
\text { guidelines }\end{array}$ \\
\hline
\end{tabular}

FEPA = Federal Environment Protection Agency (now Federal Ministry of Environment, Nigeria)

DPR = Department of Petroleum Resources (Nigeria)

Table 5: Average Values (Concentrations) of Physicochemical Characteristics and heavy metals of study area compared with some National and International Drinking Water Standards

\begin{tabular}{|c|c|c|c|c|c|c|c|}
\hline Parameters & $\begin{array}{l}\text { Results from } \\
\text { present } \\
\text { study of } \\
\text { Benin River }\end{array}$ & $\begin{array}{c}\text { Max. } \\
\text { Permissible } \\
\text { Level of the } \\
\text { National } \\
\text { Drinking } \\
\text { Water } \\
\text { Standards, } \\
\text { Nigeria } \\
\text { (SON, 2007) }\end{array}$ & $\begin{array}{l}\text { Health based } \\
\text { guideline of } \\
\text { WHO’s } \\
\text { Drinking } \\
\text { Water } \\
\text { Standards, } \\
2006 \\
\text { (WHO, } \\
\text { 2006) }\end{array}$ & $\begin{array}{c}\text { Max. } \\
\text { Contaminant } \\
\text { level of } \\
\text { USA } \\
\text { Drinking } \\
\text { Water } \\
\text { Standard } \\
\text { (USEPA, } \\
\text { 2004) }\end{array}$ & $\begin{array}{c}\text { Max. } \\
\text { Acceptable } \\
\text { level of } \\
\text { Canadian } \\
\text { Drinking } \\
\text { Water } \\
\text { Standards } \\
\text { (CCREM, } \\
\text { 1987) }\end{array}$ & $\begin{array}{c}\text { Max. } \\
\text { Admissible } \\
\text { Concentratio } \\
\text { n of EEC } \\
\text { Drinking } \\
\text { Water } \\
\text { Standards } \\
\text { (Sayre, } \\
\text { 1988) }\end{array}$ & $\begin{array}{c}\text { Permissible } \\
\text { Limit of } \\
\text { FEPA, } \\
\text { Nigeria } \\
\text { Water } \\
\text { Quality: } \\
\text { Drinking } \\
\text { Water } \\
\text { (FEPA, } \\
\text { 1991) } \\
\end{array}$ \\
\hline Temp. ${ }^{0} \mathrm{C}$ & $30.9 \pm 1.0$ & Ambient & & & & & \\
\hline $\mathrm{pH}$ at $25^{\circ} \mathrm{C}$ & $6.02 \pm 0.09$ & No guideline & No guideline & $6.5-8.5^{*}$ & $6.5-8.5$ & $6.5-8.5$ & $6.5-8.5$ \\
\hline TSS $\left(\mathrm{mgl}^{-1}\right)$ & $6.6 \pm 1.7$ & No guideline & No guideline & No guideline & No guideline & No guideline & No guideline \\
\hline $\operatorname{TDS}\left(\mathrm{mgl}^{-1}\right)$ & $22.4 \pm 5.8$ & No guideline & No guideline & $500 *$ & No guideline & No guideline & No guideline \\
\hline DO $\left(\mathrm{mgl}^{-1}\right)$ & $2.96 \pm 0.90$ & No guideline & No guideline & No guideline & No guideline & No guideline & No guideline \\
\hline $\mathrm{BOD}_{5}\left(\mathrm{mgl}^{-1}\right)$ & $6.4 \pm 2.5$ & No guideline & No guideline & No guideline & No guideline & No guideline & No guideline \\
\hline $\operatorname{COD}\left(\mathrm{mgl}^{-1}\right)$ & $80 \pm 38$ & No guideline & No guideline & No guideline & No guideline & No guideline & No guideline \\
\hline$O \& G\left(\mu \mathrm{gl}^{-1}\right.$ & $2270 \pm 480$ & No guideline & No guideline & No guideline & No guideline & No guideline & $50.0^{*}$ \\
\hline TPH $\left(\mu \mathrm{gl}^{-1}\right)$ & $2010 \pm 340$ & No guideline & No guideline & No guideline & No guideline & No guideline & 50.0 \\
\hline $\mathrm{Ni}\left(\mu \mathrm{gl}^{-1}\right)$ & $1880 \pm 630$ & No guideline & 70.0 & No guideline & No guideline & No guideline & 50.0 \\
\hline $\left.\mathrm{Cd}(\mu \mathrm{gl})^{-1}\right)$ & $3.0 \pm 5.3$ & 3.00 & 3.00 & 5.00 & 5.00 & 5.00 & 10.00 \\
\hline $\mathrm{Pb}\left(\mu \mathrm{gl}^{-1}\right)$ & $146 \pm 55$ & 10.0 & 10.0 & 15.0 & 50.0 & 50.0 & 50.0 \\
\hline $\operatorname{Cr}\left(\mu \mathrm{gl}^{-1}\right)$ & $0.40 \pm 0.59$ & 50.0 & 50.0 & 100 & 50.0 & 50.0 & 50.0 \\
\hline $\mathrm{Zn}\left(\mu \mathrm{gl}^{-1}\right)$ & $62 \pm 42$ & No guideline & No guideline & No guideline & 5000 & 100 & 5000 \\
\hline
\end{tabular}

*Secondary Maximum Contaminant level of U.S.A. Secondary CCREM = Canadian Council of Resources and Environment Drinking water Standards (non-enforceable)

USEPA = United States Environmental Protection Agency Ministers

WHO $=$ World Health Organization

EEC $=$ European Economic Community (now European Union)

FEPA = Federal Environmental Protection Agency (now Federal Minstry of Environment) 
Table 6: Average Values of Physicochemical Characteristics of Water and heavy metals of study area water compared with some guidelines for non-drinking uses of Water

\begin{tabular}{|c|c|c|c|c|c|c|c|c|c|c|c|}
\hline 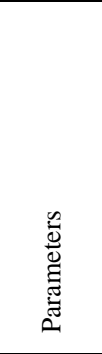 & $\begin{array}{c}\text { Averag } \\
\text { e value } \\
\text { of each } \\
\text { parame } \\
\text { ter }\end{array}$ & $\begin{array}{l}\text { Canadian } \\
\text { WQGs: } \\
\text { Pulp and } \\
\text { Paper } \\
\text { Industry } \\
\text { (Fine } \\
\text { Paper) } \\
\text { (CCREM, } \\
\text { 1987) }\end{array}$ & $\begin{array}{l}\text { Canadian } \\
\text { WQGs: } \\
\text { Iron \& } \\
\text { Steel } \\
\text { Industry } \\
\text { (Manufactu } \\
\text { re) } \\
\text { (CCREM, } \\
\text { 1987) }\end{array}$ & $\begin{array}{l}\text { FWPCA } \\
1968 \\
\text { Guideline: } \\
\text { Petroleum } \\
\text { Industry } \\
\text { (Van der } \\
\text { Leeden et } \\
\text { al., 1990) }\end{array}$ & $\begin{array}{l}\text { Canadian } \\
\text { WQGs: } \\
\text { Power } \\
\text { generating } \\
\text { industry } \\
\text { (Boiler } \\
\text { Feedwate) } \\
\text { (CCREM, } \\
\text { 1987) }\end{array}$ & $\begin{array}{c}\text { Canadian } \\
\text { WQGs: } \\
\text { Beverage } \\
\text { Industry } \\
\text { (Food } \\
\text { Canning, } \\
\text { Freezedrie } \\
\text { d } \\
\text { (CCREM, } \\
\text { 1987) }\end{array}$ & $\begin{array}{l}\text { FAO1985G } \\
\text { uideline: } \\
\text { irrigation } \\
\text { water } \\
\text { (Limiting } \\
\text { conc.) (Van } \\
\text { der Leeden } \\
\text { et al., 1990) }\end{array}$ & $\begin{array}{l}\text { CSWQCB } \\
1963 \\
\text { Guideline } \\
\text { s: Aquatic } \\
\text { life } \\
\text { protection } \\
\text { (freshwate } \\
\text { r) (Van } \\
\text { der } \\
\text { Leeden et } \\
\text { al., 1990) }\end{array}$ & $\begin{array}{c}\text { Canadian } \\
\text { Water } \\
\text { Quality } \\
\text { guideline: } \\
\text { Recreatio } \\
\text { nal Water } \\
\text { (Water } \\
\text { contact } \\
\text { limiting) } \\
\text { (CCREM, } \\
\text { 1987) }\end{array}$ & $\begin{array}{l}\text { FEPA } \\
\text { guideline: } \\
\text { Textile } \\
\text { Industry } \\
\text { (Dyeing } \\
\text { Process) } \\
\text { (FEPA, } \\
\text { 1991) }\end{array}$ & $\begin{array}{c}\text { CSWQCB } \\
1963 \\
\text { Gudelines } \\
: \\
\text { Livestock } \\
\text { Water } \\
\text { (Limiting } \\
\text { concn.) } \\
\text { (Van der } \\
\text { Leeden et } \\
\text { al., 1990) }\end{array}$ \\
\hline $\begin{array}{l}\text { Temp. } \\
{ }^{0} \mathrm{C}\end{array}$ & $\begin{array}{l}30.9 \\
\pm 1.0\end{array}$ & $\begin{array}{c}\text { No } \\
\text { guideline }\end{array}$ & $<38$ & $\begin{array}{c}\text { No } \\
\text { guideline }\end{array}$ & $\begin{array}{c}\text { No } \\
\text { guideline }\end{array}$ & $\begin{array}{c}\text { No } \\
\text { guideline }\end{array}$ & $\begin{array}{c}\text { No } \\
\text { guideline }\end{array}$ & $\begin{array}{c}\text { No } \\
\text { guideline }\end{array}$ & 50 & $\begin{array}{c}\text { No } \\
\text { guideline }\end{array}$ & $\begin{array}{c}\text { No } \\
\text { guideline }\end{array}$ \\
\hline $\begin{array}{l}\mathrm{pH} \\
\text { at } 25^{0} \mathrm{C}\end{array}$ & $\begin{array}{c}6.02 \\
\pm 0.09\end{array}$ & $\begin{array}{c}\text { No } \\
\text { guideline }\end{array}$ & $6.8-7.0$ & $6.0-9.0$ & $8.8-9.4$ & $6.8-8.5$ & $7.0-8.5$ & $6.5-8.5$ & $6.0-10.0$ & $7.5-10.0$ & $5.6-9.0$ \\
\hline $\begin{array}{l}\text { TSS } \\
\left(\mathrm{mgl}^{-1}\right)\end{array}$ & $\begin{array}{c}6.6 \\
\pm 1.7\end{array}$ & $<10.0$ & $\begin{array}{c}\text { No } \\
\text { guideline }\end{array}$ & $<10.0$ & $<0.05$ & $<10.0$ & $\begin{array}{c}\text { No } \\
\text { guideline }\end{array}$ & $\begin{array}{c}\text { No } \\
\text { guideline }\end{array}$ & $\begin{array}{c}\text { No } \\
\text { guideline }\end{array}$ & $<5.00$ & $\begin{array}{c}\text { No } \\
\text { guideline }\end{array}$ \\
\hline $\begin{array}{l}\text { TDS } \\
\left(\mathrm{mgl}^{-1}\right)\end{array}$ & $\begin{array}{l}22.4 \\
\pm 5.8\end{array}$ & $<200$ & $\begin{array}{c}\text { No } \\
\text { guideline }\end{array}$ & $<750$ & $<0.5$ & $<500$ & $<1500$ & $\begin{array}{c}\text { No } \\
\text { guideline }\end{array}$ & $\begin{array}{c}\text { No } \\
\text { guideline }\end{array}$ & $<100$ & $\begin{array}{c}\text { No } \\
\text { guideline }\end{array}$ \\
\hline $\begin{array}{l}\text { DO } \\
\left(\mathrm{mgl}^{-1}\right)\end{array}$ & $\begin{array}{c}2.96 \\
\pm 0.90\end{array}$ & $\begin{array}{c}\text { No } \\
\text { guideline }\end{array}$ & $\begin{array}{c}\text { No } \\
\text { guideline }\end{array}$ & $\begin{array}{c}\text { No } \\
\text { guideline }\end{array}$ & $<0.007$ & $\begin{array}{c}\text { No } \\
\text { guideline }\end{array}$ & $\begin{array}{c}\text { No } \\
\text { guideline }\end{array}$ & $\begin{array}{c}\text { No } \\
\text { guideline }\end{array}$ & $\begin{array}{c}\text { No } \\
\text { guideline }\end{array}$ & $\begin{array}{l}7.5 \text { or } \\
\text { more }\end{array}$ & $\begin{array}{c}\text { No } \\
\text { guideline }\end{array}$ \\
\hline $\mathrm{BOD}_{5}$ & $\begin{array}{c}6.4 \\
\pm 2.5\end{array}$ & - & - & - & - & - & - & - & - & $<1.0$ & - \\
\hline $\begin{array}{l}\text { COD } \\
\left(\mathrm{mgl}^{-1}\right)\end{array}$ & $\begin{array}{c}80 \\
\pm 38\end{array}$ & $\begin{array}{c}\text { No } \\
\text { guideline }\end{array}$ & $\begin{array}{c}\text { No } \\
\text { guideline }\end{array}$ & $\begin{array}{c}\text { No } \\
\text { guideline }\end{array}$ & $<1.0$ & $\begin{array}{c}\text { No } \\
\text { guideline }\end{array}$ & $\begin{array}{c}\text { No } \\
\text { guideline }\end{array}$ & $\begin{array}{c}\text { No } \\
\text { guideline }\end{array}$ & $\begin{array}{c}\text { No } \\
\text { guideline }\end{array}$ & $\begin{array}{c}\text { No } \\
\text { guideline }\end{array}$ & $\begin{array}{c}\text { No } \\
\text { guideline }\end{array}$ \\
\hline $\begin{array}{l}O \& \text { \& G } \\
\left(\mu g^{-1}\right)\end{array}$ & $\begin{array}{l}2270 \\
\pm 480\end{array}$ & - & ND & - & - & - & - & 0.00 & 5000 & - & - \\
\hline $\begin{array}{l}\mathrm{TPH} \\
\left(\mu g l^{-1}\right)\end{array}$ & $\begin{array}{l}2010 \\
\pm 340\end{array}$ & - & - & - & - & - & - & 0.00 & 5000 & - & - \\
\hline $\begin{array}{l}\mathrm{Ni} \\
\left(\mu \mathrm{gl}^{-1}\right)\end{array}$ & $\begin{array}{l}1880 \\
\pm 630\end{array}$ & - & - & - & - & - & 200 & 1100 & - & - & 1000 \\
\hline $\begin{array}{l}\mathrm{Cd} \\
\left(\mu g l^{-1}\right)\end{array}$ & $\begin{array}{c}3.0 \\
\pm 5.3\end{array}$ & - & - & - & - & - & 10.0 & 1160 & - & - & 50.0 \\
\hline $\begin{array}{l}\mathrm{Pb} \\
\left(\mu \mathrm{gl}^{-1}\right)\end{array}$ & $\begin{array}{r}146 \\
\pm 55\end{array}$ & - & - & - & - & - & - & 1340 & - & - & 100 \\
\hline $\begin{array}{l}\mathrm{Cr} \\
\left(\mu g l^{-1}\right)\end{array}$ & $\begin{array}{c}0.40 \\
\pm 0.59\end{array}$ & - & - & - & - & - & 100 & - & - & - & 1000 \\
\hline $\begin{array}{l}\mathrm{Zn} \\
\left(\mu \mathrm{gl}^{-1}\right)\end{array}$ & $\begin{array}{c}62 \\
\pm 42 \\
\end{array}$ & - & - & - & $<10.0$ & - & 2000 & 100 & - & - & 25000 \\
\hline
\end{tabular}

ND $=$ Not Detected $\quad$ CSWQCB $=$ California State Water Quality Control Board $\quad$ NS $=$ Not Specified

FWPCA= Federal Water Pollution Control Administration CCREM = Canadian council of Resource and environment Ministers

FAO $=$ Food and Agricultural organization FEPA $=$ Federal environmental Protection Agency (Now Federal Ministry of environment

WQGs, The average COD value $(80 \pm 83 \mathrm{mg} / \mathrm{L})$ exceeds guideline value for boiler feed water of the power generating industry $(<1.00 \mathrm{mg} / \mathrm{L})$ of the Canadian WQGs). The average value of $\mathrm{O} \& \mathrm{G}$ $(2270 \pm 480 \mathrm{mg} / \mathrm{L})$ and $\mathrm{TPH}(2010 \pm 34 \mathrm{mg} / \mathrm{l})$ exceeded guideline value for Aquatic life protection (freshwater) (ND) of the California State Water Quality Control Board (Van der Leeden et al., 1990). The average concentration of nickel in study area $(1880 \pm 630 \mu \mathrm{g} / \mathrm{L})$ exceeded guideline values for irrigation water (limiting concentrations) (200 $\mu g / L)$ of the Food and agricultural Organization WQGs (Van der Leeden et al., 1990), Aquatic life protection (freshwater) $(1160 \mu \mathrm{g} / \mathrm{L})$ of the
California State Water Quality Control Board WQGs (Van der Leeden et al., 1990) and livestock water (Limiting concentrations) $(1000 \mu \mathrm{g} / \mathrm{l})$ of the California State Water Quality Control Board WQGs. The average concentration of $\mathrm{Pb}$ in study area water $(146 \pm 55 \mu \mathrm{g} / \mathrm{L})$ exceeded guideline value for livestock rearing water (limiting concentration) $(100, \mu \mathrm{g} / \mathrm{L})$ of the California State Water Quality Control Board WQGs (Van der Leeden et al., 1990). It can be seen that the water is not suitable for all the non drinking uses listed. It should however be cautioned here that apart from that by FEPA, these guidelines are strictly not enforceable in Nigeria, these comparisons were 
Quality characteristics of effluent receiving waters

Table 3: Water Quality Characteristic of some other Rivers compared with Benin River in the present study

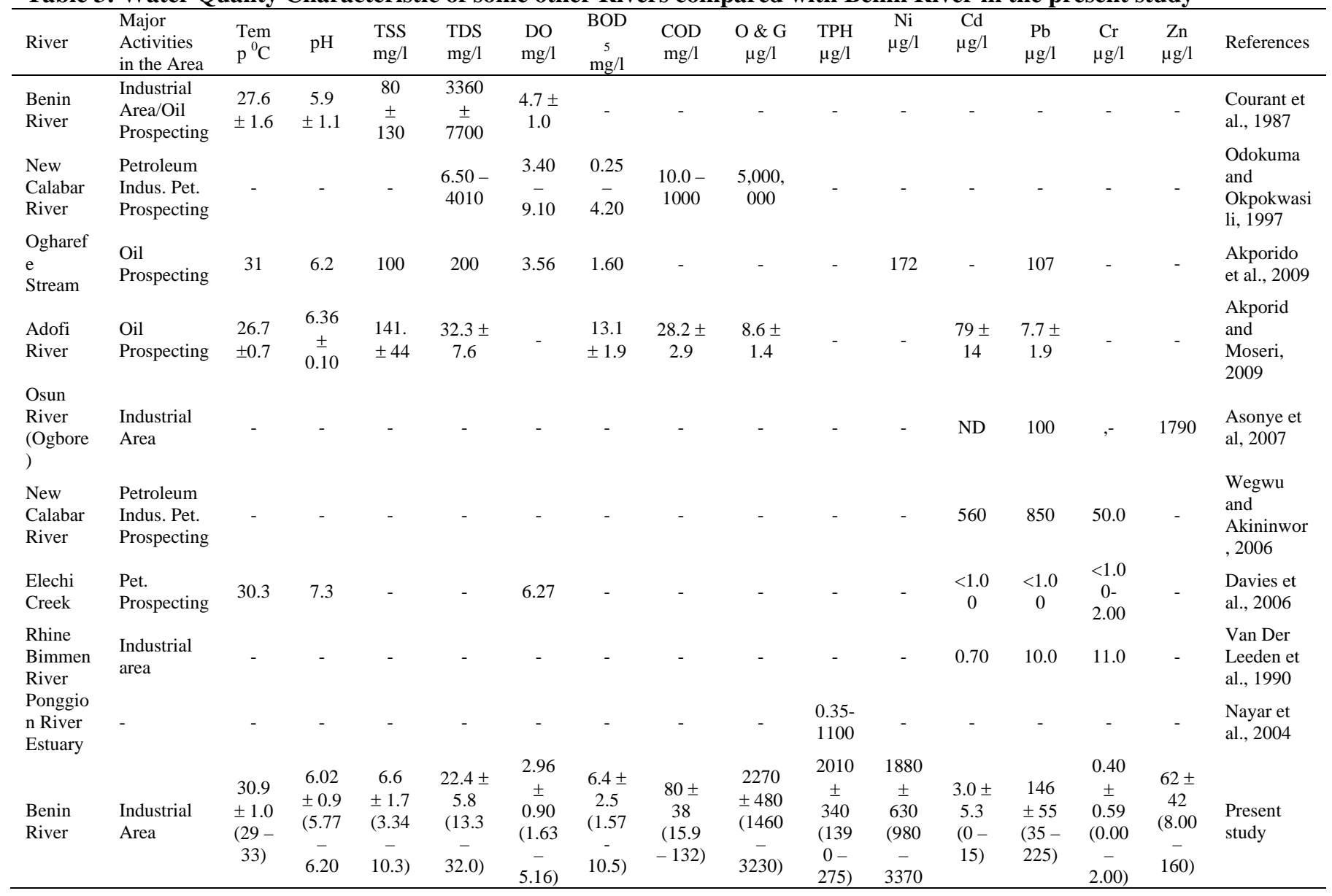

made to assess the quality of the water of the present study. The water of the study area was classified into group IV (Prati et al., 1971). Using BOD indices, the water of the study area falls into BOD indices $4-8$ (i.e. group IV) which means that the water is polluted the water need to be rigorously treated before being used for drinking purpose. A Pearson (2-tailed) correlation of the concentrations of parameters in the study shows that the following pairs correlated strongly and their correlation coefficient are significant at 0.01 confidence level $\mathrm{BOD}_{5}$ and TDS (correlation coefficient $=0.529$ ), $\mathrm{BOD}_{5}$ and DO (correlation coefficient $=0.415$ ), $\mathrm{TPH}$ and O\&G (correlation coefficient $=0.855$ ), Cd and COD (correlation coefficient $=0.410$ ), $\mathrm{Zn}$ and TDS (correlation coefficient $=0.410$ ), $\mathrm{Zn}$ and $\mathrm{BOD}_{5}$ (correlation coefficient $=0.441$ ) and $\mathrm{Zn}$ and O\&G (correlation coefficient $=0.627$ ). Also $\mathrm{Zn}$ and $\mathrm{TPH}$ (correlation coefficient $=0.333$ ) correlated strongly and the correlation coefficient is significant at 0.05 confidence level. Members of these pairs are either interdependent on each other (e.g. O\&G and TPH) or they have identical source. $\mathrm{Zn}$ and TPH must have entered the river from the effluents of the lubricating oil factory. A comparison of the results obtained in similar studies elsewhere with the results for the present study are given in Table 5. It is observed that most of the results obtained for the study area were comparable with results obtained for other rivers elsewhere. Some of the results were however higher or lower than these other results. The average COD value for Benin River in the present study $\left(80 \pm 38 \mathrm{mgl}^{-1}\right)$ or the range $\left(15.9-132 \mathrm{mgl}^{-1}\right)$ is comparable with those obtained for New Calabar River $(10.0$ - 1000 $\left.\mathrm{mgl}^{-1}\right)$ and Adofi River $\left(28.2 \pm 2.9 \mathrm{mgl}^{-1}\right)$. The average value of oil and grease obtained for Benin river in the present study $\left(2,270 \pm 480 \mu \mathrm{gl}^{-1}\right)$ or the 
range 1460 - $3230 \mathrm{\mu gl}^{-1}$ ) is lower than the average value obtained for New Calabar River $(5,000,000$ $\mathrm{ugl}^{-1}$ ). The average concentration of TPH of Benin River in the present study $\left(2010 \pm 340 \mathrm{\mu gl}^{-1}\right)$ or the range $\left(1390-2750 \mathrm{\mu gl}^{-1}\right)$ is comparable with that obtained for Pougsion River Estuary (0.38 - 1100 $\left.\mu \mathrm{gl}^{-1}\right)$. The average value of Ni obtained for Benin River in the present study $\left(1880 \pm 630{\mu \mathrm{gl}^{-1}}^{-1}\right)$ or the range $\left(980-3370 \mathrm{\mu gl}^{-1}\right)$ is much higher than that obtained for Ogharefe Stream $\left(172 \mu \mathrm{gl}^{-1}\right)$. Also the average concentration of $\mathrm{Pb}$ obtained for Benin

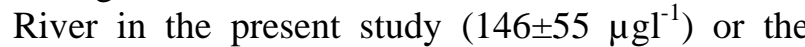
range (35 - $225 \mu \mathrm{gl}-1)$ is comparable with those obtained for Ogharefe Stream $\left(107 \mu \mathrm{gl}^{-1}\right)$ and Osun River $\left(100 \mu \mathrm{gl}^{-1}\right)$, It is higher than that for Adofi River $\left(7.7 \pm 1.9{\mu \mathrm{gl}^{-1}}^{-1}\right.$, and Elechi Creek $\left(<1.00 \mu \mathrm{gl}^{-}\right.$ ${ }^{1}$ ).It is lower than that for New Calabar River (850 $\left.\mu \mathrm{gl}^{-1}\right)$.

\section{Conclusion}

The results obtained in the study indicate that the water is polluted with respect to its use as potable water. The concentration of $\mathrm{Ni}$ and $\mathrm{Pb}$ are higher than guideline values, the average $\mathrm{pH}$ falls lower than $\mathrm{pH}$ range of some of the guidelines for drinking water and guidelines for some nondrinking uses of water (i.e. higher acidity).The average concentration of oil and grease and TPH obtained for the study area are also very high (higher than some guideline values) and this also indicate that pollution may have its source in the Lube oil producing factory situated in that area. Water was classified as group IV (Prati et al., 1971, which means the water is polluted with respect to its use for drinking. The presence of high concentrations of the toxic metals $(\mathrm{Ni}$ and $\mathrm{Pb})$ and the oil variables (O\&G and $\mathrm{TPH}$ ) has grave consequences for the health of humans and higher animals in the area. Fishing and collection of other animal resources is one of the important occupation of the people in this area. Crop farming is another important occupation. These pollutants can easily enter into the food chain involving himans and higher animals by being available for plant uptake and ingestion by smaller fishes and animal dwelling the river. The presence of these pollutants in the food chain will result in adverse effect on the health of humans and higher animals. It has been observed in this study that this pollutants get to the river through the the effluents from the lubricating oil producing factory. This bad situation can be curtailed by making sure the factory treats its effluent before disposal into the River. Effluent limitation guidelines have been established by relevant governmental Agencies i.e.: Environmental Guideline and standard for the Petroleum Industry in Nigeria by Department of Petrleum Resources in Nigeria (DPR) and National Guidelines and Standards by Federal ministry of Environment (FMEnv.) (Formerly known as Federal environmental Protection Agency). It is however observed that there are lapses in the monitoring of the various industries for compliance with the established guidelines. The Federal Government of Nigeria should ensure that the various industries are properly monitored for compliance with the established guidelines to achieve a healthier environment

\section{Acknowledgement}

The Department of Chemistry Delta State University is hereby acknowledged for making its laboratory facilities available for the study. $\mathrm{Mr}$ Ebruba Osagu assistance in sample collection and in certain aspects of the analysis of samples is here acknowledge

\section{References}

Akporido, S. O. and Imah, C.E., 2009. Estimation of $\mathrm{pH}$, total concentration of selected heavy metals in soil and speciation studies of the metals in soil of an auto-mechanic village in Effurun, Delta State, Nigeria. Journal of Research in Physical Sciences, 5 (2): $14-19$

Akporido, S. O. and Moseri, E.M., 2009.An assessment of effluent quality from Michelin factory Utagbe-Uno and water quality of the receiving Adofi River, Delta State, Nigeria. Journal of Research in Physical Science, 5(1): 125 - 132.

Akporido, S.O., Emuobonuvie, J. and Akporido, C.E., 2000. Study of the quality characteristics of surface and underground water in Sapele and Ogharefe Oil Producing areas of Delta State, Nigeria. Nigerian Journal of Science and Environment,2:17 - 22

Allens, S.E., 1989. Chemical Analysis of Ecological Materials. Blackwell Scientific Publications, Oxford

APHA - AWWA - WEF, 1995.Standard methods for the examination of Water and Wastewater.American Public Health Association American Water Works Association - Water Environment Federation. New York

Asonye, C.C., Okolie, N.P., Okenwa, E.E. and Iwuayanwu, U.G., 2007. Some physical characteristics and heavy metal profiles of 
Nigerian rivers, streams and water ways.African Journal.of Biotechnology,6 (5): $617-624$

Canadian Council of Resource and Environment Ministers (CCREM), 1987 Canadian Water Quality Guidelines. Canadian Council of Resources and Environment Ministers. Winnipeg Canada

Courant, R., Powel, B. And Micheal, J., 1987. Water - type classification for Niger Delta. In proceedings of 1985 Seminar on the Petroleum Industry and the Nigerian Environment.The Petroleum inspectorate, NNPC and Environment Planning Division Federal Ministry of Works and Housing, Lagos. 387p

Davies, G.A., Allison, M.E. and Uyi, A.S., 2006.Bioaccumulation of heavy metal in water, sediment and periwinkles (Tympanotonousfuscatusvar radula) from the Elechi creek, Niger Delta. African J. of Biotech., 5 (10), 968 - 975 .

Davies, O. A. and Abowei, J. F. N., 2009. Sediment quality of lower reaches of Okpoka Creek, Niger Delta, Nigeria, European J. of sci. Res., 26 (3), $437-442$

Directorate of Land and Survey, 2000. Map of Warri North Local Government Area, .Delta State, Nigeria. Directorate of Land and Survey, Delta State, Nigeria

DPR, Effluent guidelines, Department of Petroleum Resources, Victoria Island Lagos, Nigeria (2002).

Ekpo, B. O., Oyo-Ita, O. E., Oros, D. R. and Simoneit, B. R. T., 2012. Distribution and sources of Polycyclic aromatic hydrocarbons in surface sediments from Cross River estuary S. E. Niger Delta, Environmental Monitoring and Assessment, 184 (2): 1037 - 1047

FEPA, 1991.National guidelines and Standards.FEPA (Now Federal Ministry of Environment Nigeria), P.M.B. 265 GarkiF.C.T. Abuja Nigeria).

Forstner, U. and Whittman, G.T.W., 1983. Metals in the aquatic environment. Springer-Verlag Berlin Heidelberg, New York, Tokyo

GESAMP., 1993. Impacts of Oil and related Chemicals and Wastes in the Marine environment. London U.K.Group of Experts on the Scientific Aspects of Marine Pollution (GESAMP) Reports and Studies: No 50 International Marine Organization

Horsefall, M. Jr. and Spiff, A. I., 2002. Distribution and partitioning of trace metals in sediment of lower reaches of the New Calabarriver, Port Harcourt, Nigeria. Environental Monitoring and Assessment, 78(3), $309-326$

Iwegbue, C. M. A., William, E. S. and Nwajei, G. E., 2008. Characteristic levels of total petroleum hydrocarbon in soil profiles of automobile mechanic waste dumps, International. Journal of Soil Science, 3: 48-51

Kocasoy, G., 2003. Environmental exploitation of hazardous wastes by developing countries. Journal of Environmental Protection and Ecology 4 (3):587 - 593

Luiselli, L., Akani, G. C. and Politano, E., 2006. Effects of habitat alteration caused by petrochemical activities and oil spills on the habitat use and interspecific relationships among four species of afrotropical freshwater turtles. Biodiversity.and Conservation.15 (11): 3756-3767
Luiselli, L., Akani, G. C., Politan O. E., Odegbune, E.,2004. and Bello, O., Dietary shift of sympatric freshwater turtle in pristine and oilpolluted habitats of the Niger Delta Southern Nigeria. Herpetologica Journal, 14(2), 57-64

National Research Council (NRC), 2003. Oil in the Sea III: Inputs, fates and effects. National Academic Press Washington D. C. $265 \mathrm{pp}$

Nayar, S., Goh, B. P. L. And Chou, L. M., 2004. The impact of petroleum hydrocarbons (diesel) on periphyton in an impacted tropical estuary based on insitu microcosm. J. of Experimental Marine Biology and Ecology, 32(2):213- 232

Nduka, J. K., Orisakwe, O. E. and Ezenwa, T. E., 2009.Effect of effluents from Warri refinery and petrochemical company on water and soil qualities of "Contiguous host and impacted on communities of Delta state, Nigeria.The open Environmental.and Toxicological Journal, 1: $11-17$

Nduka, J. K..andOrisakwe, O. E., 2011. Water - quality issues in the Niger Delta of Nigeria: A look at heavy metal levels and some physicochemical properties. Environmental Science.and Pollution Research, 18 (2): 237 - 246

Nwilo, P.C and Badejo, O.T., 2007 Comps, impacts and management of oil spill pollution along the Nigerian coastal areas. Retrieved 20/05/2007 from http://www.fig.net/pub/figpub/pub36/Chapters/chapter8 pdf

Obire, O., Tamuno, D.C. and Wemedo, S.A., 2003.Physico-chemical quality of Elechi creek in Port Harcourt. Journal of Applied Science and Environnmental Management,7 (1): 43 - 49

OdokumaL.O. and Okpokwasili, G.C., 2004 Seasonal ecology of hydrocarbon-utilizing microbes in the surface waters of a river.Environmental Monitoring and Assessment, 27(3), 175-191

Olajire, A.A., Altenburger, R., Kuster, E. and Brack, W.,2005. Chemical and ecotoxicological assessment of polycyclic aromatic hydrocarbon contaminated sediments of Niger Delta, Southern Nigeria, Science.of the Total Environment, 340 (1 - 3), 123 - 136

Omo-Irabor, O. O., Olobaniyi, S. B., Akunma, J., Venus, V., Maina, J. M. and Paradzayi, C., 2011.Mangrove vulnerability modelling in parts of Western Niger Delta, Nigeria using satellite images, GIS techniques and spatial multi-criteria analysis (SMCA). Environmental Monitoring and Assessment, $178(1-4)$ : 39 - 51

Onianwa, P.C., Ipeayeda, A. and Emurotu, J.E. (2001).Water quality of the urban rivers and streams of Ibadan Nigeria.Environmental Education and Information, 20 (2):107 - 120.

Otukunefor, T.V. and Obiukwu, C., 2005. Impact of Refinery effluent on thephysicochemical properties of awater body in the Niger Delta. Applied Ecology and Environmental Research, 3(1): 61

Prati, L. Pavenello, R. and Pesaria,F.,1971. Assessment of Surface Water quality by a single index pollution,water Research, 5, 741751

Puyate, Y. T., Rim-Rukeh, A. and Awatefe, S. I., 2007. Metal pollution assessment and particle size distribution of bottom sediment of Orogodo River, Agbor, Delta State, Nigeria. Journal of Applied Science Research, Research 3(12): 2056 - 2061

Sayre, I.M. International standards for drinking water, 1998. J. of Wat.Works Assoc., $88(1), 1-5)$. 


\section{Samuel Omorovie Akporido}

Standard Organization of Nigeria (SON) (2007). Nigeria Standard for drinking water quality retrieved 09/08/2008 from http://www.unicef/ng/nigeria-publications-Nigeria.

United Nation Development Programme (UNDP), 2006. Niger Delta Human

Development.http://hdr.undp.org/en/reports/nationalreports/africa /nigeria/name,3368,en.html. 09/19/2011

United Nation Environment Programme (UNEP), 2011. Environmental assessment of Ogoniland.United 39. Nation Environment Programme (UNEP), Nairobi

USEPA, 2004. Drinking water standards and health advisories.Retrieved 29/08/2007 from $<$ http://www.epagerwaterscience.

Uzoekwe, S. A. and Oghosanine, F. A., 2011.The effect of refinery and petrochemical effluent on water quality of Ubeji Creek, Warri, southern Nigeria.Ethopian Journal of Environmental studies and Management,4 (2): 107 - 116
Vander Leeden, F., Troise, F.L., and Todd, D.K. 1990, The water Encyclopaedia. Second Edition. Chelsea. Lewis Publishers

Wegwu, M.O. and Akininwor, J.O., 2006. Assessment of heavy metal profile of the New Calabar River and its impact on juvenile Clariasgariepinu. Chemistry and Biodiversity.,3(1): $79-87$

WHO, 2006.WHO's drinking water standards 2006. Retrieved 09/08/2009 from http://www.lenntech.com/WHO’s-drinkingwater-standards06.htm.

Williams, A. B. and Benson, N. U., 2010 Interseasonal hydrological characteristics and variabilities in surface water of tropical estuarine ecosystems within Niger Delta, Nigeria. Environ. Monit.and Assess., 165 (1 - 4), 399 - 404. 